\title{
Application of titanium machining chips in welding consumables for wear-resistant hardfacing
}

\author{
José Gedael Fagundes Junior, Rodolfo da Silva Manera, Ruís Camargo \\ Tokimatsu, Vicente Afonso Ventrella \& Juno Gallego
}

To cite this article: José Gedael Fagundes Junior, Rodolfo da Silva Manera, Ruís Camargo Tokimatsu, Vicente Afonso Ventrella \& Juno Gallego (2016) Application of titanium machining chips in welding consumables for wear-resistant hardfacing, Welding International, 30:7, 520-526, DOI: 10.1080/09507116.2015.1096521

To link to this article: https://doi.org/10.1080/09507116.2015.1096521

册 Published online: 06 Feb 2016.

Submit your article to this journal

山 Article views: 72

View Crossmark data ¿ 


\title{
Application of titanium machining chips in welding consumables for wear- resistant hardfacing
}

\author{
José Gedael Fagundes Juniora, Rodolfo da Silva Manera ${ }^{b}$, Ruís Camargo Tokimatsuc, Vicente Afonso Ventrellac \\ and Juno Gallegoc
}

aPPGEM, UNESP - Ilha Solteira, Ilha Solteira, Brazil; 'bProduct Management, Autocam Medical, Campinas, Brazil; 'Universidade Estadual Paulista, UNESP - Ilha Solteira, Ilha Solteira, Brazil

\begin{abstract}
Equipment of sugar cane plants and mineral extraction are submitted to severe abrasive wear conditions. Welded hardfacings are usually applied to repair this kind of damage, where commercial chromium/carbon-rich welding consumables have usually been employed. In the present work we investigated the microstructure of experimental hardfacings made by addition of residues (chips) collected from the machining of ASTM F67 (unalloyed Ti, grade 4) alloy. Mixtures with different carbide-formers ( $\mathrm{Cr} / \mathrm{Nb}$ ferro-alloys) were also tested. Two layers of 'pure' chips (Ti), chips plus Fe- $\mathrm{Cr}(\mathrm{Ti}-\mathrm{Cr})$, and chips plus $\mathrm{Fe}-\mathrm{Nb}$ ( $\mathrm{Ti}-\mathrm{Nb})$ were applied on low-carbon steel specimens by the GTAW/TIG process. The microstructure of hardfacing layers was observed by optical and scanning electron microscopy (SEM) equipped with EDS microanalysis. The microstructural characterization has determined that carbide distributions change significantly with the chemical nature of the hardfacing. SEM observations coupled with EDS microanalysis have confirmed the formation of complex carbides within the metal weld, whose stoichiometry was determined by X-ray diffraction (XRD) analysis. Mixed carbides of MC type and some cementite have been found. As a result it was suggested that use of ASTM F67 chips as carbide formers for composition of welding consumables can contribute to improved wear resistance of hardfacings, if compared with traditional chromium-based hardfacings.
\end{abstract}

\section{KEYWORDS}

GTAW/TIG welding; hardfacing; carbides; titanium chips recycling; microstructure; wear resistance

\section{Introduction}

Titanium alloys ASTM F67 (pure Ti, grade 4) and ASTM F136 (Ti-6Al-4 V alloy) found quick and effective acceptance in the market for prostheses and dental implants owing to the excellent biomedical properties, especially corrosion resistance, biocompatibility, bioadhesion, and mechanical properties similar to bone tissues [1]. The implants are made in various formats and sizes, normally with diameter from 3 to $5 \mathrm{~mm}$ and length from 15 to 20 $\mathrm{mm}$. Serial production of these complex-geometry parts is carried out by machining cylindrical bars in machines with Computer Numerical Control. The volume of material removed (chips) is quite significant, normally $40 \%$ of the volume of the part, or greater in some cases. There is not yet a market for this type of waste (swarf) in Brazil, so that its disposal is quite expensive for the companies in this sector.

Coatings that are resistant to abrasive wear are formed from hard metal layers deposited by welding, normally hardened with chromium carbides. The consumables used in welding use ferrochrome with high carbon content in their composition, so that formation of carbides in the fusion pool is possible. Most of the scientific works in this area relate to the mechanical and structural characterization of hard coatings containing chromium carbides [2-4]. The alloys ASTM F67 and ASTM F136 consist of chemical elements that are carbide formers, such as titanium and vanadium, making it technically possible to employ this type of waste (chips) for producing hard coatings. Addition of titanium and other carbide formers in the welding of coatings with high chromium and carbon content has been investigated by various researchers [5-8]. The present work aims to investigate the microstructure of experimental hard coatings, with emphasis on the formation of primary carbides, where chips of ASTM F67 alloy (pure $\mathrm{Ti}$, grade 4) were used in the manufacture of consumables for arc welding with a tungsten electrode and gas shielding (GTAW/TIG). The formation of carbides during welding of mixtures of chips with ferrochrome or ferroniobium was also assessed.

\section{Materials and methods}

The ASTM F67 titanium chips were collected and underwent a cleaning process, to remove residues from machining. Figure 1(a) illustrates the typical appearance 


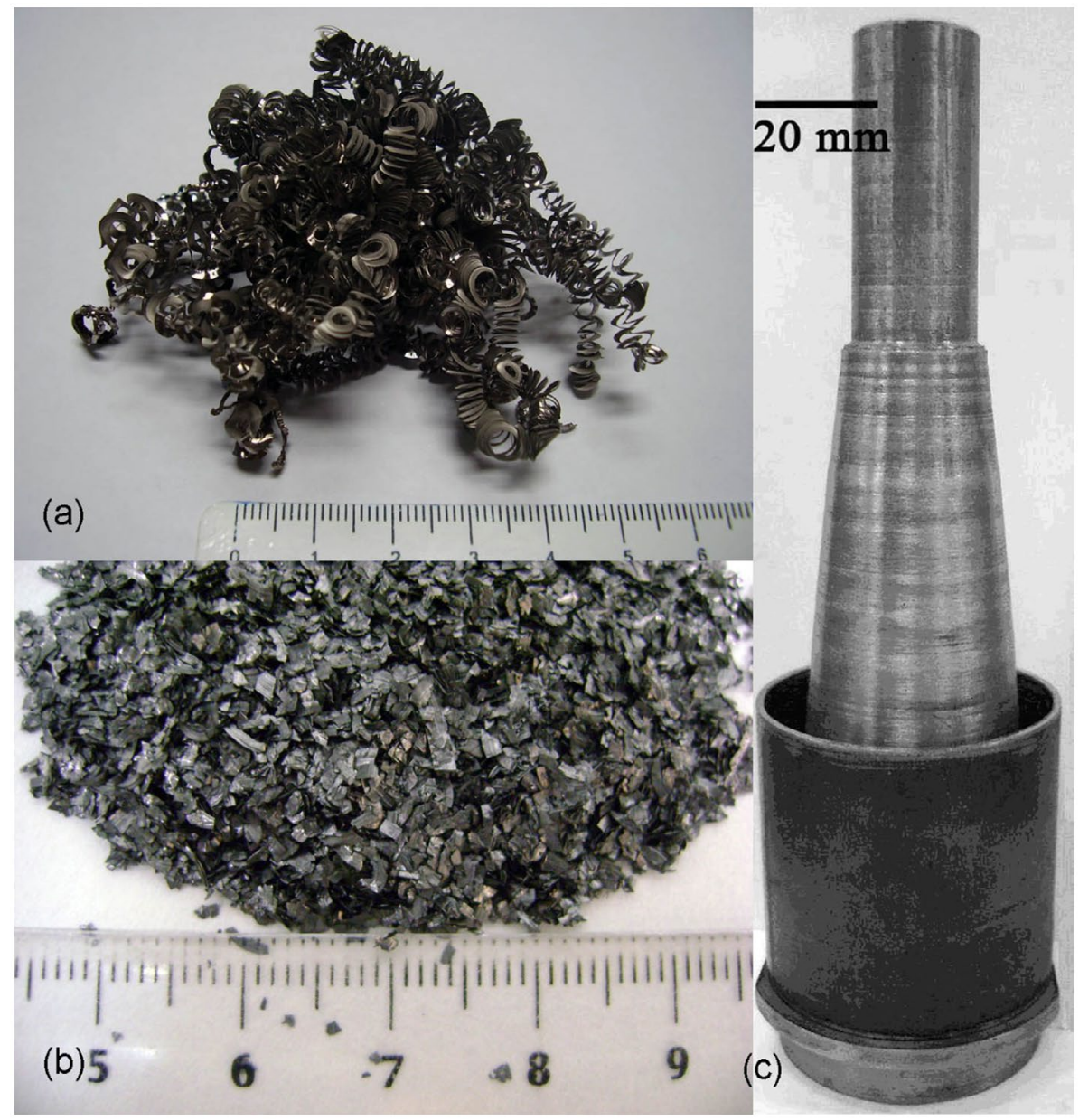

Figure 1. Appearance of the chips of ASTM F67 alloy before (a) and after (b) grinding in the device shown in (c).

Table 1. Chemical compositions of the raw materials used (wt $\%)$.

\begin{tabular}{lccccccc}
\hline & $\mathrm{Ti}$ & $\mathrm{Cr}$ & $\mathrm{Nb}$ & $\mathrm{C}$ & $\mathrm{Si}$ & $\mathrm{P}$ & $\mathrm{Fe}$ \\
\hline ASTM F67 & Bal. & - & - & 0.08 & - & - & 0.50 \\
Fe-Cr & - & 55.2 & - & 7.70 & 3.50 & 0.03 & Bal. \\
Fe-Nb & - & - & 64.7 & 0.09 & 2.70 & 0.20 & Bal. \\
AISI 304 & - & 18.0 & - & 0.08 & 1.00 & 0.04 & Bal. \\
\hline
\end{tabular}

Note: Bal. denotes balance by weight.

of the material after this cleaning step. To make it possible for the waste to be inserted in tubes of AISI 304 austenitic stainless steel, the chips were ground, Figure 1(b). The device used for breaking up the long spirals is shown in Figure 1(c) and was coupled to a vertical column drilling machine, used at low rotary speed (90 rpm). Ferrochrome and ferroniobium in powder form were used as additives, with the chemical compositions given in Table 1.

For carbide formation, it was necessary to add carbon to the chips and to $\mathrm{Fe}-\mathrm{Nb}$. Table 1 shows the chemical composition, by weight, of the raw materials used for production of the coatings, where it can be seen that only the ferrochrome contains carbon in sufficient quantity for carbide formation. Taking into account the stoichiometry for carbides of the MC type (cubic), addition of $3 \mathrm{~g}$ of graphite in powder form per $10 \mathrm{~g}$ of titanium chips was calculated, while only $1.2 \mathrm{~g}$ of graphite was required per $10 \mathrm{~g}$ of ferroniobium. The mixtures in powder form had addition of $2 \mathrm{wt} \%$ of sodium silicate, a compound used as vitrifying agent.

The mixtures were moistened with a small amount of distilled water to form a paste that could easily be introduced into the tubes of AISI 304 stainless steel, which had outside diameter of $4.0 \mathrm{~mm}$, wall thickness of $0.25 \mathrm{~mm}$, and length of $250 \mathrm{~mm}$. The pasty mixture was compacted inside the tubes using a metal rod. For welding the coatings, three types of consumables were produced: (i) rods consisting of 'pure chips', identified hereinafter by 'Ti'; (ii) rods with a mixture of chips and $\mathrm{Fe}-\mathrm{Cr}$ in proportions 1:1 by weight, identified by 'Ti-Cr', and (iii) rods with a mixture of chips and $\mathrm{Fe}-\mathrm{Nb}$ in proportions $1: 1$ by weight, identified by ' $\mathrm{Ti}-\mathrm{Nb}$ '. After preparation, the rods were stored in a stove at $80^{\circ} \mathrm{C}$ for at least $24 \mathrm{~h}$, for complete dehydration. 
Table 2. Nominal proportion of the carbide formers in the mixtures used in the rods produced.

\begin{tabular}{lcccc}
\hline Rod & \multicolumn{4}{c}{ Carbide former (wt\%) } \\
\cline { 2 - 5 } & $\mathrm{Ti}$ & $\mathrm{Cr}$ & $\mathrm{Nb}$ & Total \\
\hline $\mathrm{Ti}$ & 99.0 & - & - & 99.0 \\
$\mathrm{Ti}-\mathrm{Cr}$ & 49.5 & 27.6 & - & 77.1 \\
$\mathrm{Ti}-\mathrm{Nb}$ & 49.5 & - & 32.3 & 81.8 \\
\hline
\end{tabular}

For deposition of the coatings, test specimens were prepared, made from low-carbon structural steel (ASTM A36), machined with nominal dimensions $25 \times 9.5 \times 76 \mathrm{~mm}$. Fusion of the $\mathrm{Ti}$, Ti-Cr, and $\mathrm{Ti}-\mathrm{Nb}$ rods employed manual GTAW/TIG welding, so that the workpieces were coated with two layers consisting of longitudinal beads at the length of the base metal. During welding, the electric current varied between 150 and $160 \mathrm{~A}$, employing straight polarity with a negative EWTh-2 electrode $(\Phi 2.4 \mathrm{~mm})$. Pure argon was used for shielding the fusion pool at an average flow rate of $10 \mathrm{l}$ per minute. After welding, the coatings were brushed and ground carefully so as to remove the minimum possible amount of material and guarantee a flat surface free from impurities, for metallographic preparation of the surface and for carrying out hardness tests.

The cross-section of the hard coatings was prepared in specimens embedded in polyester resin, and the polished surfaces comply with the conventional metallographic method. The finish was provided by mechanical polishing with alumina, in granulometries of 1 and $0.3 \mu \mathrm{m}$. Metallographic etching was performed with a reagent consisting of $5 \mathrm{~g}$ of copper chloride, $100 \mathrm{ml}$ of hydrochloric acid, $100 \mathrm{ml}$ of ethanol, and $100 \mathrm{ml}$ of distilled water. The microstructure was examined by light microscopy and scanning electron microscopy (SEM), and microanalysis was performed by energy dispersive spectroscopy (EDS).

The phases in the coating were determined by X-ray diffraction (XRD) using a diffractometer equipped with a copper tube ( $\mathrm{Cu} K_{\alpha}=1.5405 \AA$ ) and a graphite monochromator. The intensity diffracted by the specimens was recorded in the range from $30^{\circ}$ to $100^{\circ}$, scanned at a rate of $2^{\circ}$ per minute. Identification of the phases was based on the CIF crystallographic files, which were consulted in the Inorganic Crystal Structure Database [9]. The volume fraction of the phases identified was not determined. The hardness variation in the coatings was assessed by measuring the Vickers hardness, using a standard load of $30 \mathrm{kgff}$ for 15 s [10]. For statistical analysis, at least 10 measurements were taken per specimen. The results were processed with a level of significance of 95\%, employing analysis of variance (ANOVA) for assessing the differences between the measurements performed.

\section{Results and discussion}

The GTAW/TIG torch supplied concentrated thermal energy in the fusion pool, in the order of $4000-4250 \mathrm{~J} \mathrm{~s}^{-1}$. This energy was sufficient to promote fusion of the compounds used in the manufacturing of the rods and to dilute the carbide formers in the molten weld metal. The rods used in this study - Ti (chips), $\mathrm{Ti}-\mathrm{Cr}$, and $\mathrm{Ti}-\mathrm{Nb}$ - have different contents of carbide formers, as shown in Table 2. This does not take into account the composition of the stainless steel tube used, but considering the chemical compositions presented in Table 1, it is assumed that up to $99 \%$ of the weight of the Ti rods may contribute to the formation of carbides of the TiC type. Similarly, up to $77.1 \%$ of the weight of the $\mathrm{Ti}-\mathrm{Cr}$ rods might result in the formation of $(\mathrm{Ti}, \mathrm{Cr}) \mathrm{C}$ mixed carbides within the fusion pool during welding. This proportion for the $\mathrm{Ti}-\mathrm{Nb}$ rods would be $81.8 \%$ of the added weight and might produce carbides of the ( $\mathrm{Ti}, \mathrm{Nb}) \mathrm{C}$ type.

The formation of different amounts of carbides by weight, Table 2, and the variation in the chemical composition of the carbides formed, contributed to the variations in weldability of the rods produced. The formation and the chemical stability of the compounds can be interpreted from thermodynamic parameters such as the change in Gibbs free energy $\Delta G^{\circ}$ for carbide formation [11-13]. The ratio of $\Delta G^{\circ}$ to the temperature may serve as a thermodynamic criterion for establishing the order of formation of carbides in the fusion pool [12]. Accordingly, the sequence for nucleation of 'pure' cubic carbides from GTAW/TIG welding of the rods is expected to be $\mathrm{TiC}-\mathrm{NbC}-\mathrm{Cr}_{23} \mathrm{C}_{6}-\mathrm{Fe}_{3} \mathrm{C}$. The melting point of these carbides decreases in the same sequence, being higher for $\mathrm{TiC}(3340 \mathrm{~K})$ and lower for cementite (1498 K) [13]. The latter has an orthorhombic crystal structure and is only given for reference.

Thus, welding of the Ti rods, with the highest titanium contents, required the GTAW/TIG torch to be moved at lower speed during manual welding. The superheating caused major warpage and cracking in the Ti coating. The mixture of titanium chips with ferroalloys in the $\mathrm{Ti}-\mathrm{Cr}$ and $\mathrm{Ti}-\mathrm{Nb}$ rods contributed to the formation of complex carbides, whose formation required a smaller change in the free energy. Thus, the thermal cycle applied to the $\mathrm{Ti}-\mathrm{Cr}$ and $\mathrm{Ti}-\mathrm{Nb}$ coatings attenuated the superheating of the substrate used, reducing the levels of warpage and cracking. The additions of chromium and niobium to the weld metal also affected the hardness and microstructure of the coatings, and will be seen later.

Examination by light microscopy showed that the coatings have a microstructure consisting predominantly of particles of second phase embedded in the matrix. Observing the specimens in the just-polished 

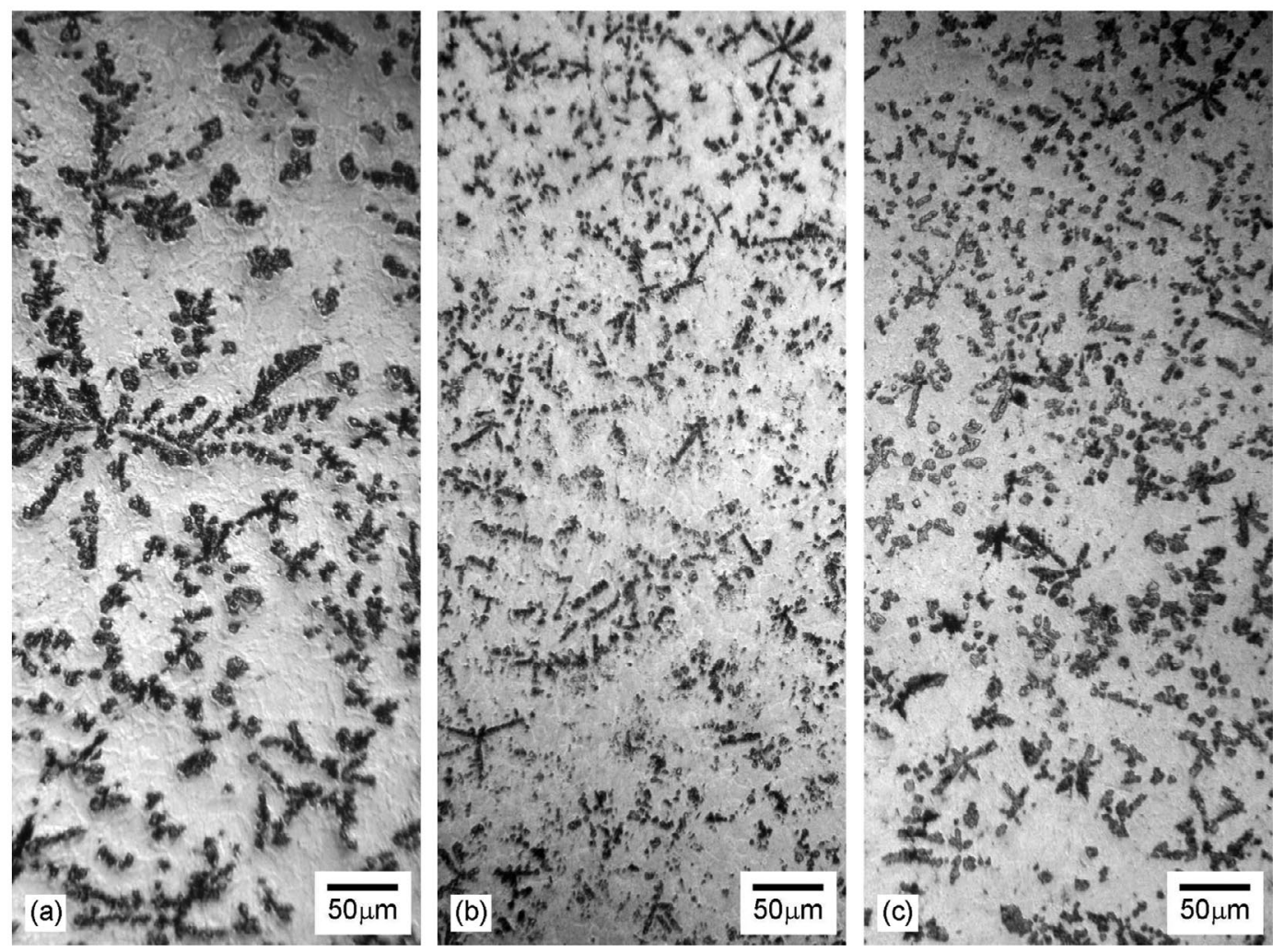

Figure 2. Optical micrographs showing particles of second phase found in the normal section of coatings $\mathrm{Ti}$ (a), $\mathrm{Ti}-\mathrm{Cr}(\mathrm{b}) \mathrm{and} \mathrm{Ti}-\mathrm{Nb}$ (c). Nominal magnification: $180 \times$.

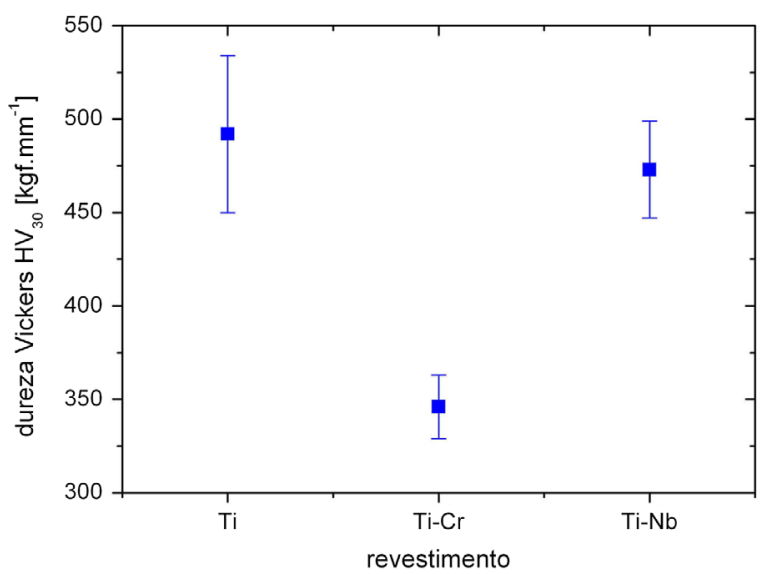

Figure 3. Variation of the Vickers hardness in the $\mathrm{Ti}, \mathrm{Ti}-\mathrm{Cr}$ and $\mathrm{Ti}-\mathrm{Nb}$ coatings. dureza Vickers = Vickers hardness; revestimento $=$ coating.

condition, it can be seen that there is a significant difference in hardness between the particles and the matrix, as a characteristic relief formed where the (harder) particles stand out from the plane of the matrix [14]. Figure 2 shows typical examples of the precipitation observed in the coatings under investigation, where the variation in morphology of the particles of second phase can be seen. Measurements of Vickers hardness suggest that these particles are responsible for the hardening of the matrix, Figure 3, constituting the carbides formed during GTAW/TIG welding of the coatings. ANOVA confirms that there is no significant difference between the hardnesses of the Ti and Ti-Nb coatings. The same does not happen with the hardness of the Ti-Cr layer, which is significantly lower than the others.

SEM constitutes an important tool for observing details that are imperceptible in the light microscope, combining images with information of a chemical nature. Figure 4(a) shows the dendritic microstructure found in the Ti coating. The titanium carbides appear dark in the compositional contrast obtained with backscattered electrons (BSE) [15]. Microanalyses by EDS confirmed that the titanium content of the carbides varied between 90 and $95 \%$ by weight (wt\%), in addition to the presence of iron (3-4.5 wt\%) and chromium (1-2 wt\%). The titanium carbides found in the Ti coating had low contents of iron and chromium, Figure 4(b), a result that was attributed to the greater availability and chemical affinity between carbon and titanium relative to the other carbide formers [11]. The interdendritic pockets show significant titanium depletion, containing at most $30 \mathrm{wt} \%$ of the element. The principal chemical element in these regions is iron, which varied from 60 to $70 \mathrm{wt} \%$.

The Ti-Cr coating, Figure 5(a), had a microstructure constituted of dendritic branches consisting of particles with globular or star-like morphology. The dark BSE contrast suggests that they are particles formed with chemical elements that are lighter than the ferrous matrix. In fact, EDS microanalysis of these particles indicates that they are composed on an average of $45 \%$ of titanium, whereas the content of this element 

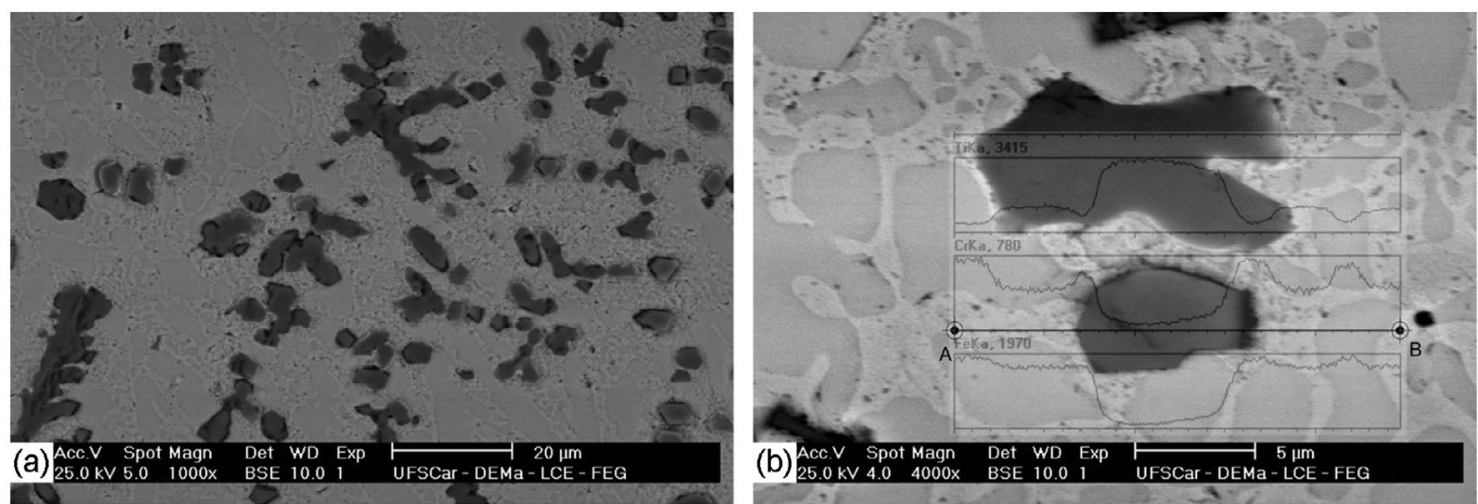

Figure 4. SEM micrographs with contrast of backscattered electrons (BSE) of the Ti coating. Panoramic image of carbides in (a) and variation of the chemical composition (EDS) between points $A$ and $B$ in (b).
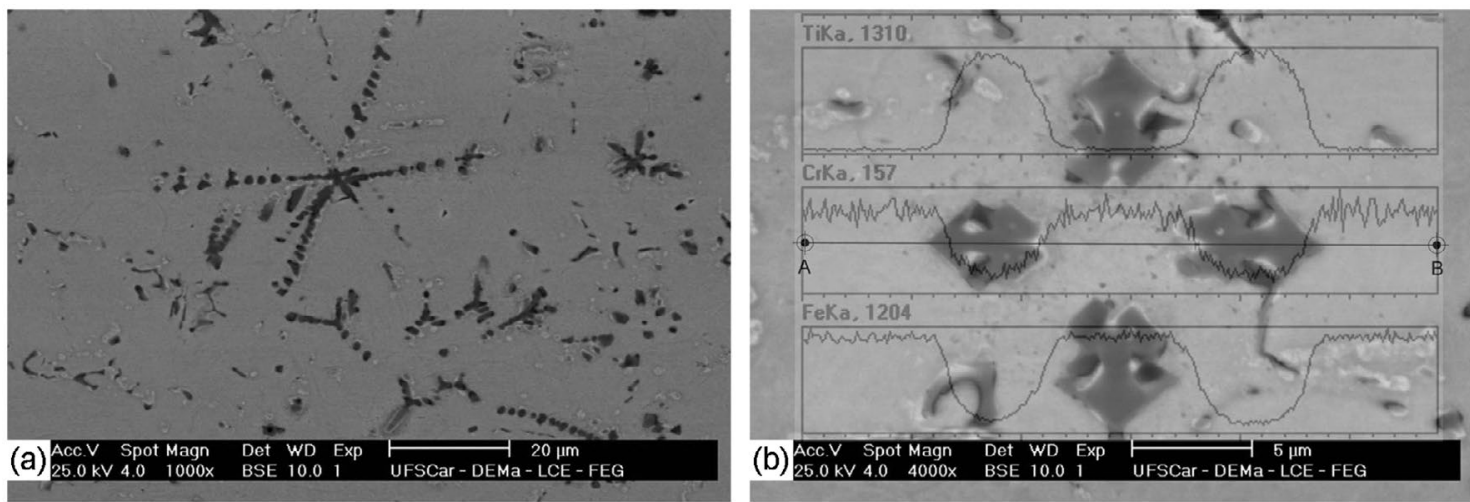

Figure 5. SEM micrographs with backscattered electron (BSE) contrast of the Ti-Cr coating. Panoramic image of carbides in (a) and variation of the chemical composition (EDS) between points $A$ and $B$ in (b).
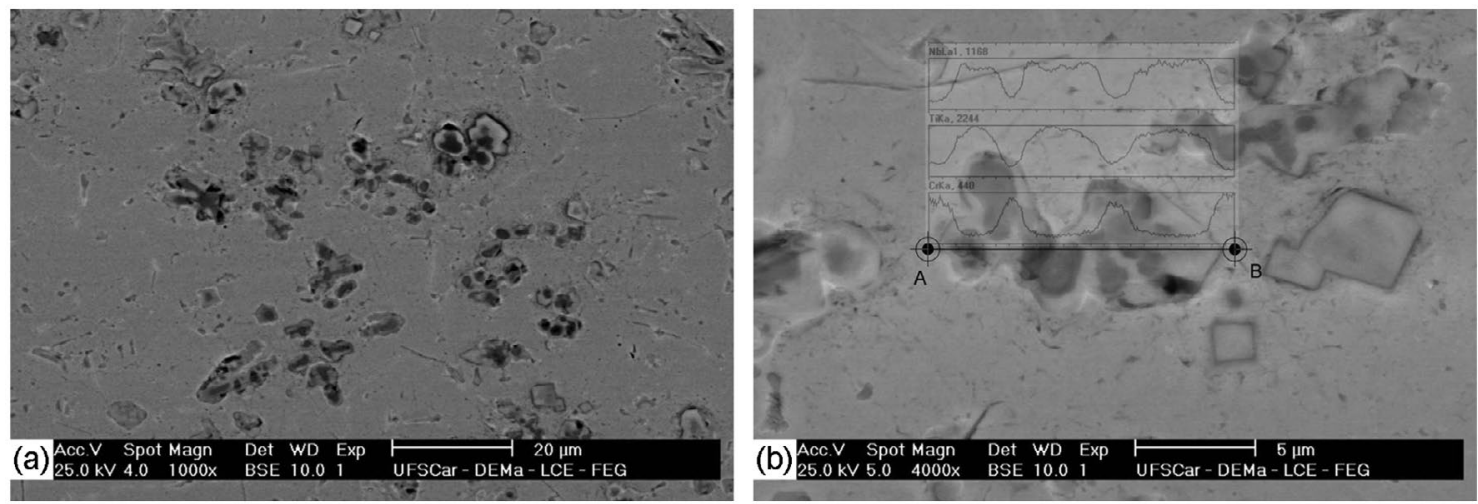

Figure 6. SEM micrographs with backscattered electron (BSE) contrast of the Ti-Nb coating. Panoramic image of carbides in (a) and variation of the chemical composition (EDS) between points $A$ and $B$ in (b).

in the ferrous matrix was only $1 \%$. The dispersion of the particles was fairly irregular, probably promoted by the dilution and thermal cycle imparted during welding of the coating. Chromium participated, between 3 and $5 \mathrm{wt} \%$, in the formation of the particles. Similar concentrations were found for nickel and silicon. However, there was an increase in the chromium content, between 5 and $10 \mathrm{wt} \%$, in the chemical composition of ferritic matrix. For nickel this concentration reached $2 \mathrm{wt} \%$, a concentration similar to that found in the Ti coating.
This variation in the chemical composition is consistent with the results disclosed by Wu et al. [16], where layers of chromium carbides were able to nucleate on the primary titanium carbides formed in hypereutectic white cast iron.

The microstructure of the $\mathrm{Ti}-\mathrm{Nb}$ coating is shown in Figure 6(a). Carbides with complex morphology were observed, noting effective participation of both niobium and of titanium in the formation of primary carbides. These elements have strong chemical affinity for carbon, 


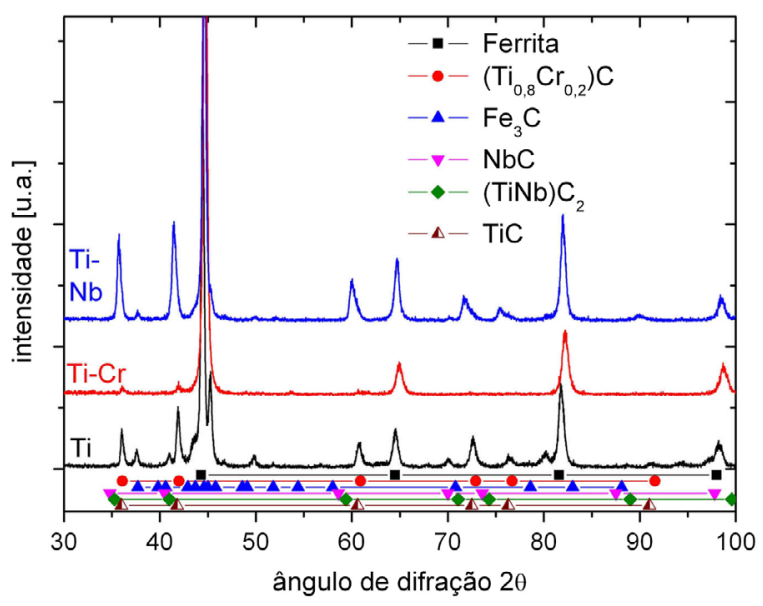

Figure 7. X-ray diffraction of the $\mathrm{Ti}, \mathrm{Ti}-\mathrm{Cr}$ and $\mathrm{Ti}-\mathrm{Nb}$ coatings. Intensidade [u.a.] = intensity [a.u.]; Ferrita = Ferrite; ângulo de difração $2 \theta=$ diffraction angle $2 \theta$.

greater than chromium [11]. EDS microanalysis confirmed that titanium and niobium displayed cooperative behaviour in the formation of carbides, restricting the partition of carbon with chromium and iron. Even so, it was possible to observe, Figure 6(b), concentration gradients of the carbide formers within one and the same particle. The regions with darker BSE contrast had lower concentrations of niobium, approximately $35 \mathrm{wt} \%$, while in the particles that had a lighter and more uniform appearance the niobium content exceeded $42 \mathrm{wt} \%$. The titanium content in these same particles fluctuated between 48 and $52 \mathrm{wt} \%$. Iron (8-10\%), chromium (1-1.5\%), and silicon (up to $0.3 \%$ ) also form part of the chemical composition (by weight) of these carbides. The ferritic matrix in the $\mathrm{Ti}-\mathrm{Nb}$ coatings consists 85 to $90 \%$ of iron, 8 to $12 \%$ of chromium and 2.5 to $3 \%$ of titanium, by weight.

Characterization by XRD confirmed that the ferrous matrix in all the coatings consisted of ferrite with body-centred cubic structure, Figure 7. However, the diffractograms also show peaks diffracted by other phases. The positions of the diffraction angle $2 \theta$ of the peaks identified were consistent with the CIF crystallographic files [9] of the carbides indicated in Table 3. It can be seen that there was a tendency for formation of cubic compounds, i.e. in the coatings formed from one or two carbide formers (titanium, chromium or niobium). In the Ti coating, formation of the carbide
$\mathrm{TiC}$ is confirmed. In the $\mathrm{Ti}-\mathrm{Cr}$ and $\mathrm{Ti}-\mathrm{Nb}$ coatings, 'mixed' carbides were identified, where both the main carbide formers are in substitutional solid solution. The structures found correspond to $\left(\mathrm{Ti}_{0.8} \mathrm{Cr}_{0.2}\right) \mathrm{C}$ and ( $\mathrm{Ti}$ $\mathrm{Nb}) \mathrm{C}_{2}$, both cubic. The low intensity diffracted by the cementite $\mathrm{Fe}_{3} \mathrm{C}$ was attributed to low volume fraction of this compound in the specimens analysed and may suggest that the carbon added during production of the $\mathrm{Ti}, \mathrm{Ti}-\mathrm{Cr}$ and $\mathrm{Ti}-\mathrm{Nb}$ rods was sufficient for formation of the titanium-rich carbides.

From the qualitative standpoint, it is speculated that the particles that are morphologically large and not excessively faceted would be more indicated for creating an abrasion-resistant coating, as there would be better stress distribution during wear $[17,18]$. Fragmentation of the carbides may occur during wear, so that these act as abrasive particles in motion. The primary carbides found in the specimens grow easily within the interdendritic pockets, very often resulting in crystals hundreds of micrometres in length. The orientation of the growth axis of these carbides is affected by the welding process, so that a cluster of these particles has its growth axis in an orientation almost parallel to the surface of the coating. In this case, the particles would have less interaction with the matrix, which would become detached from it more easily and would accelerate the wear process. The dendritic growth may result in an irregular distribution of the carbides over the surface, leading to anisotropic behaviour of the coating with respect to abrasive wear resistance, which will be investigated in future studies.

\section{Conclusions}

$\mathrm{Ti}, \mathrm{Ti}-\mathrm{Cr}$ and $\mathrm{Ti}-\mathrm{Nb}$ hard coatings were produced during welding by GTAW/TIG.

Fusion of the consumables prepared from a mixture of chips of ASTM F67 titanium with graphite (Ti), as well as the mixtures prepared with ferroalloys ( $\mathrm{Fe}-\mathrm{Cr}$ and $\mathrm{Fe}-\mathrm{Nb}$ ), allowed formation of particles with dendritic morphology in the weld metal.

XRD identified these particles as cubic titanium carbides with stoichiometries $\mathrm{TiC},\left(\mathrm{Ti}_{0.8} \mathrm{Cr}_{2}\right) \mathrm{C}$ and $(\mathrm{TiNb}) \mathrm{C}_{2}$, depending on the carbide formers present in the consumable.

The presence of the carbides promoted an increase in hardness of the weld metal of the coatings analysed,

Table 3. Crystallographic parameters of the phases found by X-ray diffraction [9].

\begin{tabular}{lcccc}
\hline Phase & ICSD file & Structure (S.G.) & \multicolumn{2}{c}{ Lattice parameter (Å) } \\
\cline { 3 - 5 } & & & a & b \\
\hline Ferrite & 64795 & BCC (229) & - \\
$\mathrm{TiC}$ & 44494 & FCC (225) & 4.318 & - \\
$\left(\mathrm{Ti}_{0.8} \mathrm{Cr}_{2}\right) \mathrm{C}$ & 53106 & FCC (225) & 4.299 & - \\
$(\mathrm{Ti} \mathrm{Nb}) \mathrm{C}_{2}$ & 77219 & FCC (225) & - & - \\
$\mathrm{Fe}_{3} \mathrm{C}$ & 38308 & ORT (62) & 5.396 & - \\
$\mathrm{NbC}$ & 159872 & FCC (225) & 4.092 & - \\
\hline
\end{tabular}

Note: S.G. corresponds to the space group of the phase or microconstituent. 
which was higher in the Ti coating $\left(490 \mathrm{HV}_{30}\right)$ and lower in the Ti-Cr coating $\left(345 \mathrm{HV}_{30}\right)$.

The hardening of the coatings accompanied the increase in the proportion of carbide formers in the composition of the rods used in welding, which varied from $77.1 \mathrm{wt} \%$ for the $\mathrm{Ti}-\mathrm{Cr}$ coating to $99.0 \mathrm{wt} \%$ for the Ti coating.

\section{Acknowledgements}

The authors thank the Structural Characterization Laboratory of DEMa/UFSCar for support in microstructural characterization, CBMM and COFEL for the raw materials (ferroalloys) and the grants from the CNPq (J.G.F.J. and J.G.) during development of this work.

\section{Disclosure statement}

No potential conflict of interest was reported by the authors.

\section{References}

[1] Lütjering G, Williams JC. Titanium. Heidelberg: Springer-Verlag Berlin; 2003. p. 345-349.

[2] Buchanan VF, Shipway PH, McCartney DG. Microstructure and abrasive wear behaviour of shielded metal arc welding hardfacings used in the sugarcane industry. Wear. 2007;263:99-110.

[3] Berns H, Fischer A. Microstructure of $\mathrm{Fe}-\mathrm{Cr}-\mathrm{C}$ hardfacing alloys with additions of $\mathrm{Nb}, \mathrm{Ti}$ and, $\mathrm{B}$. Mater. Charact. 1997;39:499-527.

[4] Sabet H, Khierandish S, Mirdamadi S, et al. The microstructure and abrasive wear resistance of $\mathrm{Fe}-$ $\mathrm{Cr}-\mathrm{C}$ hardfacing alloys with the composition of hypoeutectic, eutectic, and hypereutectic. Tribol. Lett. 2011;44:237-245.

[5] Lima AC, Ferraresi VA. Análise da Resistência ao Desgaste de Revestimento Duro Aplicado por Soldagem em Facas Picadoras de CanaDe-Açúcar. Soldagem e Inspeção, São Paulo. 2010;15:94-102.
[6] Lima AC, Ferraresi VA. Análise da microestrutura e da resistência ao desgaste de revestimento duro utilizado pela indústria sucroalcooleira. Soldagem \& Inspeção (Impresso). 2009;14:140-150.

[7] Buchely MF, Gutierrez JC, León LM, et al. The effect of microstructure on abrasive wear of hardfacing alloys. Wear. 2005;259:52-61.

[8] Correa EO, Alcântara NG, Tecco DG, et al. The relationship between the microstructure and abrasive resistance of a hardfacing alloy in the $\mathrm{Fe}-\mathrm{Cr}-\mathrm{C}-\mathrm{Nb}-\mathrm{V}$ system. Metall. Mater. Trans. A. 2007;38:1671-1680.

[9] Inorganic Crystal Structure Database (ICSD). Arquivos cristalográficos no formato CIF. Crystallographic Information Framework. [cited 2013 Jul]. Available from: http://www.fiz-karlsruhe.de/icsd.html

[10] American Society for Testing and Materials. E92: standard test method for Vickers hardness of metallic materials. West Conshohocken; 2003. p. 9.

[11] Shatynski SR. The thermochemistry of transition metal carbides. Oxid. Met. 1979;13:105-118.

[12] Yedong H, Zhengwei L, Huibin Q, et al. Standard free energy change of formation per unit volume: a new parameter for evaluating nucleation and growth of oxides, sulphides, carbides and nitrides. Mater. Res. Innovat. 1997;1:157-160.

[13] Coltters RG. Thermodynamics of binary metallic carbides: a review. Mater. Sci. Eng. 1985;76:1-50.

[14] Wang XH, Zou ZD, Qu SY, et al. Microstructure and wear properties of Fe-based hardfacing coating reinforced by TiC particles. J. Mater. Process. Technol. 2005;168:89-94.

[15] Goodhew PJ, Humphreys J, Beanland R. Electron microscopy and microanalysis. 3rd ed. London: Taylor \& Francis Inc; 2001. p. 251.

[16] Wu X, Xing J, Fu H, et al. Effect of titanium on the morphology of primary $\mathrm{M}_{7} \mathrm{C}_{3}$ carbides in hypereutectic high chromium white iron. Mater. Sci. Eng. A. 2007;457:180-185.

[17] Yaer X, Shimizu K, Matsumoto H, et al. Erosive wear characteristics of spheroidal carbides cast iron. Wear. 2008;264:947-957.

[18] Zum Gahr, K-H. Microstructure and wear of materials. Tribol. Ser. 1987;10: 559. 